\title{
Perbedaan Prestasi Belajar Ditinjau Berdasarkan Pola Asuh Orangtua
}

\author{
Cynthia Florencia $^{1)}$, Agoes Dariyo ${ }^{2)}$, Debora Basaria ${ }^{3)}$ \\ Fakultas Psikologi Universitas Tarumanagara \\ 1'cynthiaflorencia12@gmail.com, ${ }^{2}$ agoesd@fpsi.untar.ac.id, ${ }^{3}$ deborab@fpsi.untar.ac.id
}

\begin{abstract}
Education has always been one of the basic necessities of any individual's life. Education provides opportunities for children to learn, prepare for the future, and be able to change the lives of present and future generations. With education, people can obtain academic achievements that will be useful for his life. Academic achievement in adolescents can be influenced by parenting styles. The aim of the current study is to examine the differences in academic achievement in adolescents based on parenting styles. This study utilizes quantitative data and has 386 subjects. Data were retrieved through parenting styles questionnaires as well as grade point average (GPA). Data is processed by using One Way ANOVA. Based on the results of research, it was found that there was no differences in academic achievement in adolescents based on parenting, either by father or mother, with a p score on father parenting $=.223$ and the $p$ score on mother parenting $=.737$.
\end{abstract}

Keywords: academic achievement, parenting styles, adolescence

\begin{abstract}
ABSTRAK
Pendidikan sudah selalu menjadi kewajiban mendasar bagi hidup manusia. Pendidikan menyediakan kesempatan kepada anak-anak untuk belajar, menyiapkan masa depan, dan mampu mengubah kehidupan pada masa kini dan generasi di masa depan. Dengan pendidikan, orang-orang dapat memiliki prestasi akademik yang akan berguna dalam kehidupannya. Prestasi akademik pada remaja dapat dipengaruhi oleh pola asuh orangtua. Tujuan dari penelitian ini adalah untuk menguji perbedaan prestasi akademik remaja berdasarkan pola asuh orangtua. Penelitian ini menggunakan data kuantitatif dan memiliki 386 orang subjek. Data diperoleh dari kuesioner pola asuh dan Indeks Prestasi Akademik (IPK). Data diproses menggunakan One Way Anova. Berdasarkan hasil penelitian, ditemukan bahwa tidak ada perbedaan dalam prestasi akademik pada remaja berdasarkan pola asuh, baik oleh ayah atau ibu, dengan skor $\mathrm{p}$ pada pola asuh ayah $=.223$ dan skor p pada pola asuh ibu $=.737$.
\end{abstract}

Kata kunci: prestasi akademik, pola asuh, remaja

\section{PENDAHULUAN}

Pendidikan sangat diperlukan dalam kehidupan setiap orang. Pendidikan memberikan kesempatan kepada anak untuk belajar, tumbuh dan mempersiapkan masa depan. Pendidikan mampu mengubah kehidupan saat ini dan nasib generasi mendatang (Save the children, 2016). Menurut UU No. 20 Tahun 2003 tentang sistem pendidikan nasional menyatakan bahwa pendidikan nasional berfungsi mengembangkan kemampuan dan membentuk watak serta peradaban bangsa yang bermartabat dalam rangka mencerdaskan kehidupan bangsa. Bertujuan untuk mengembangkan potensi peserta didik agar menjadi manusia yang beriman dan bertaqwa kepada Tuhan Yang Maha Esa, berakhlak mulia, sehat, berilmu, cakap, kreatif, mandiri dan menjadi warga Negara yang demokratis serta bertanggungjawab.

Untuk mencapai tujuan dari pendidikan nasional tersebut, setiap orang yang belajar di lembaga pendidikan diharapkan memiliki prestasi belajar. Prestasi belajar pada mahasiswa dapat dilihat dari tercapainya prestasi akademik yang tinggi. Tolok ukur tercapainya prestasi akademik di universitas adalah Indeks Prestasi Kumulatif (IPK). Indeks Prestasi Kumulatif seringkali digunakan sebagai indikator utama kemampuan akademik mahasiswa (Nugrasanti, 2006).

Prestasi akademik dipengaruhi oleh faktor lingkungan keluarga. Faktor ini berasal dari pengasuhan atau sering dikenal dengan istilah pola asuh orangtua. Baumrind (1971, dalam Papalia, Feldman, \& Martorell, 2012) telah mengidentifikasikan tiga jenis pola 
asuh. Pertama adalah pola asuh authoritative yaitu pola asuh yang menekankan kemandirian dan batasan sosial. Orangtua dengan pola asuh ini menuntut anak untuk berperilaku yang baik dan tegas dalam menetapkan aturan, namun memberikan kesempatan kepada anak untuk saling bertukar pikiran maupun pendapat. Kedua adalah pola asuh authoritarian yaitu pola asuh yang menekankan pada kontrol dan kepatuhan. Orangtua dengan pola asuh ini menetapkan aturan dan mengharuskan anak untuk mematuhi peraturannya. Orangtua akan memberikan hukuman jika anak melanggar peraturannya. Ketiga adalah pola asuh permissive yaitu pola asuh yang menekankan kebebasan berperilaku dan berekspresi pada anak. Orangtua dengan pola asuh ini cenderung hangat, tidak menuntut dan tidak menetapkan aturan. Kemudian Maccoby dan Martin (dalam Papalia et al., 2012) dalam penelitiannya telah berhasil mengidentifikasi pola asuh keempat. Pola asuh ini disebut neglectful, orangtua pada pola asuh ini tidak mementingkan kebutuhan anak dan lebih mementingkan kebutuhan mereka sendiri. Maka dapat dikatakan orangtua pada pola asuh neglectful tidak memperdulikan anaknya.

Pola asuh orangtua dapat menjadi salah satu penentu pada pencapaian prestasi anak. Oleh karena itu pola asuh orangtua memiliki hubungan dengan prestasi akademik anak (Baumrind, 1971; Maccoby \& Martin, 1983 dalam Papalia, Feldman, Martorell, 2012; Khayyer \& Delacey dalam Nugrasanti, 2006; Steinberg dalam Banerjee \& Eccles, 2013; Santrock, 2016). Berdasarkan hasil penelitian dari Nurmah (2011) mengenai hubungan pola asuh orang tua dengan prestasi belajar anak usia sekolah menunjukan bahwa dari 39 responden terdapat 20 responden anak dengan pola asuh authoritative menghasilkan prestasi belajar yang tinggi. Hasil penelitian dari Tang dan Kean (2015) mengenai hubungan lingkungan rumah dengan pencapaian prestasi remaja juga menghasilkan remaja dengan pola asuh authoritative mencapai prestasi belajar yang tinggi, yaitu dari 486 responden menunjukkan hasil signifikan $\mathrm{r}=42.74$, $\mathrm{p}<$ 0.05. Kingsley (2011) juga melakukan penelitian mengenai pengaruh pola asuh authoritative pada pencapaian akademik remaja, dari 239 responden terdapat remaja yang memiliki ibu dengan pola asuh authoritative menghasilkan $\mathrm{r}=0.160, \mathrm{p}<$ 0.05 , dan yang memiliki ayah dengan pola asuh authoritative menghasilkan $\mathrm{r}=0.204$, $\mathrm{p}$ $<0.01$. Hasil tersebut menunjukkan bahwa remaja dengan pengasuhan authoritative memiliki prestasi belajar yang baik. Kemudian, Turner, Chandler dan Heffer (2009) juga telah melakukan penelitian mengenai pengaruh pola asuh orangtua, pencapaian motivasi dan kepercayaan diri terhadap prestasi akademik mahasiswa, dari 264 responden dan hasil data menunjukkan $\mathrm{F}=3.26, \mathrm{p}=.022$ dan $\mathrm{R} 2=.037$. Hasil penelitian tersebut mengindikasikan pola asuh authoritative berpengaruh secara signifikan terhadap prestasi belajar mahasiswa.

Selain pola asuh authoritative, terdapat juga beberapa hasil penelitian mengenai pola asuh authoritarian. Berdasarkan hasil penelitian dari Nurmah (2011) mengenai hubungan pola asuh orang tua dengan prestasi belajar anak usia sekolah menunjukan bahwa anak dengan pola asuh authoritarian memiliki prestasi belajar yang tinggi, yaitu dari 39 responden terdapat delapan responden anak dengan pengasuhan authoritarian. Dari delapan responden tersebut, seluruh responden memiliki prestasi belajar yang tinggi sehingga hasil menunjukkan $100 \%$. Namun pada kenyataannya terdapat beberapa hasil penelitian yang bertolak belakang. Menurut penelitian Yasmin dan Kiani (2015) mengenai peran pola asuh orangtua terhadap pencapaian nilai akademik pada mahasiswa, dari 350 responden menunjukkan bahwa anak dengan pola asuh authoritarian menghasilkan prestasi belajar yang sangat rendah, di mana hasil pengolahan data menunjukkan $\mathrm{r}=-323$. Selain itu, hasil penelitian Dehyadegary, Yacoob, Juliani dan Talib (2012) mengenai hubungan pola asuh orangtua dengan prestasi akademik pada remaja di Sirjan, Iran, dari 382 responden terdapat 52 responden anak dengan pola asuh authoritarian yaitu sekitar 13,6\% dan hasil menunjukkan bahwa anak dengan pola asuh authoritarian memiliki prestasi belajar rendah. 
Pola asuh permissive juga memiliki fenomena hasil penelitian yang berhubungan dengan prestasi belajar anak. Berdasarkan hasil penelitian Dehyadegary et al., (2012) menyatakan bahwa pola asuh permissive merupakan pola asuh yang sangat negatif terhadap prestasi belajar anak sehingga prestasi belajar anak menjadi rendah. Selain itu, Turner et al., (2009) juga telah melakukan penelitian mengenai pengaruh pola asuh orangtua, pencapaian motivasi dan kepercayaan diri terhadap prestasi akademik mahasiswa, dari 264 responden hasil penelitian menunjukkan bahwa pola asuh permissive tidak memiliki hasil yang signifikan dalam menentukan prestasi belajar anak.

Pada pengasuhan neglectful juga terdapat hasil penelitian mengenai pola asuh neglectful dengan prestasi belajar. Hasil penelitian dari Pinquart (2016) mengenai asosiasi dari pola asuh dan dimensi pola asuh dengan prestasi belajar pada anak dan remaja menunjukkan bahwa anak yang diasuh oleh pengasuhan neglectful akan memiliki prestasi belajar yang rendah, di mana hasil pengolahan data menunjukkan $\mathrm{r}=-0.23$. Menurut Martin dan Coldbert (dalam Conrad \& Sarwono, 2010) anak yang berasal dari pola asuh neglectful tidak memiliki kemampuan yang baik secara akademik maupun sosial. Anak dengan pengasuh neglectful seringkali terlibat dalam kenakalan atau perilaku antisosial saat remaja. Penelitian ini dilakukan dengan tujuan untuk mengetahui perbedaan prestasi belajar remaja ditinjau dari pola asuh orangtua.

Berdasarkan penjelasan-penjelasan tersebut, maka orangtua sangatlah berperan penting dalam perkembangan seorang remaja. Oleh karena itu, peneliti melakukan penelitian mengenai prestasi belajar pada remaja berdasarkan perbedaan pola asuh orangtua.

Prestasi belajar adalah hasil penilaian pendidik terhadap proses belajar dan hasil belajar seseorang sesuai dengan tujuan intruksional yang berkaitan dengan isi pelajaran dan perilaku yang diharapkan (Sarwono, 2010). Pada dasarnya prestasi belajar merupakan hal yang penting untuk mengetahui sejauh mana kemampuan seseorang setelah menerima pelajaran. Prestasi belajar tidak datang dengan sendirinya, melainkan ditempuh dengan cara bertahap dan berkelanjutan sehingga prestasi ini dapat menjadi acuan untuk mengetahui kemampuan siswa yang sebenarnya (Suardi, 2012). Prestasi belajar pada mahasiswa dapat dilihat dari tercapainya prestasi akademik yang tinggi. Tolak ukur tercapainya prestasi akademik di universitas adalah Indeks Prestasi Kumulatif (IPK). Indeks Prestasi Kumulatif seringkali digunakan sebagai indikator utama kemampuan akademik mahasiswa (Nugrasanti, 2006). Indeks Prestasi Kumulatif yang tinggi memiliki range nilai IPK 3.50 sampai dengan 4.00. Biasanya mahasiswa yang lulus dengan niali IPK tersebut memiliki predikat lulus dengan pujian jika kelulusan dengan masa studi maksimal 4 tahun atau 8 semester atau dikenal dengan istilah Cum Laude (Buku panduan Untar, 2016).

Kebiasaan orangtua dalam mengasuh dan membesarkan anak baik di rumah ataupun di kehidupan sehari-hari dapat menjadi sebuah pola pengasuhan yang menetap sehingga terbentuknya pola asuh orangtua. Pola asuh adalah cara orangtua dalam membesarkan anak dengan merawat, melindungi, mendidik serta mempengaruhi tingkah laku kehidupan sehari-hari anak (Baumrind, dalam Papalia, et al., 2012). Menurut Brooks (2012) pola asuh adalah istilah di mana orangtua berperan sebagai individu yang menumbuhkan semua aspek dari pertumbuhan dan perkembangan anak. Orangtua merawat, melindungi, serta memandu kehidupan baru sang anak melalui pembangunan karakter. Pola asuh adalah sebuah proses dari tindakan dan interaksi antara orangtua dan anak. Ini adalah proses di mana orangtua dapat membentuk kepribadian sang anak sejak kecil hingga tumbuh dewasa.

Terdapat berbagai jenis pola asuh yang memiliki cara serta dampak pengasuhan yang berbeda-beda. Baumrind (dalam Papalia, et al., 2012) telah membagi pola asuh ke dalam tiga jenis pola asuh yaitu: pola asuh (a) authoritative, (b) authoritarian dan (c) permissive. Berikut akan dijelaskan satupersatu setiap jenis pola asuh tersebut. 
Pertama, pola asuh authoritative merupakan pola asuh di mana orang tua bersikap responsif terhadap kebutuhan anak sekaligus menetapkan aturan bagi perilaku anaknya. Pola asuh ini menjelaskan orang tua mengasuh anak dengan mengendalikan perilaku sang anak tetapi tetap fleksibel. Orangtua membuat tuntutan yang wajar dan turut serta menjelaskan setiap alasan mengapa sang anak harus mematuhi batasan-batasan yang telah ditentukan dan memastikan sang anak mengikuti panduan tersebut. Orangtua dengan pola asuh authoritative lebih dapat menerima dan merespon pandangan anaknya dibandingkan dengan pola asuh authoritarian. Orangtua juga mengikutsetakan sang anak berpartisipasi dalam keluarga, khususnya dalam hal pengambilan keputusan. Orangtua sangat merawat dan mendukung setiap aspek kehidupan sang anak (Baumrind, dalam Shaffer, 2010)

Kedua, pola asuh authoritarian adalah pola asuh di mana orangtua kurang responsif terhadap hak dan keinginan anak, dan sangat memberikan kontrol terhadap kewajiban dan perilaku anak. Orangtua dengan gaya pengasuhan ini memiliki banyak peraturan dan sangat mengharapkan ketaatan dari sang anak tanpa menjelaskan kepada anaknya mengapa harus mematuhi semua peraturan tersebut. Orangtua sering mengandalkan taktik hukuman apabila anak tidak mentaati peraturan. Mereka cenderung memiliki sudut pandang yang berbeda dengan sang anak. Oleh karena itulah pola asuh authoritarian dikarekteristikan dengan orangtua yang memiliki kekuasaan yang kuat agar sang anak menghormati otoritas mereka (Baumrind, dalam Shaffer 2010).

Ketiga, pola asuh permissive merupakan pola asuh di mana orangtua bersikap responsif terhadap anak tetapi tidak menetapkan aturan bagi perilaku sang anak. Orangtua dengan pola asuh permissive memiliki karakteristik sedikit menuntut dan memberikan kebebasan kepada anak sehingga jarang menggunakan perintah atau kekuasaan dalam mencapai tujuan pengasuhan. Meskipun terdapat orangtua dalam pengasuhan ini yang memberikan peraturan, namun peraturan tersebut tidak konsisten diterapkan. Orangtua cenderung memberikan kebebasan sebanyak-banyaknya dan membiarkan anak melakukan sesuai dengan apa yang mereka inginkan. Orangtua memperbolehkan anak untuk mengatur dan membuat keputusan bagi diri sendiri, meskipun anak tersebut belum siap untuk itu. Selain itu orang tua juga bersikap tidak menghukum dan menerima serta menyetujui apa saja yang dilakukan anak. Orangtua dalam pola asuh ini tetap menyayangi anak tetapi menghindari pemberian perintah kepada anak (Baumrind, dalam Papalia et al., 2012).

Kemudian Maccoby dan Martin (dalam Papalia et al., 2012) telah menemukan pola asuh keempat yang disebut sebagai pola asuh neglectful. Pola asuh neglectful adalah pengasuhan di mana orangtua kurang memenuhi kebutuhan anaknya dan cenderung memenuhi kebutuhannya sendiri. Orangtua dengan pola asuh ini memiliki dukungan emosional yang rendah, rendahnya kontrol dan rendahnya penerimaan (Weiten, Dunn, dan Hammer; 2009). Menurut Papalia et al., (2012) orangtua dengan pola asuh neglectful memberikan respon yang sangat rendah terhadap apa yang dilakukan anaknya. Rendahnya pengawasan dan kepedulian serta sikap dingin orangtua cenderung bersikap membiarkan apapun yang dilakukan anak (Cobb, 2007).

Maccoby dan Martin (dalam Shaffer \& Kipp, 2010) menjelaskan dua dimensi dari pola asuh, yaitu parental responsiveness dan parental demandingness. Kecenderungan gaya mengasuh orangtua terhadap suatu dimensi akan menentukan jenis pola asuh orangtua tersebut. Parental responsiveness merupakan dimensi pola asuh di mana orangtua memiliki acceptance yang tinggi dalam pola pengasuhan. Dimensi ini dikarakteristikan dengan adanya dukungan dan perhatian penuh dari orangtua kepada anak. Orangtua penuh kasih sayang, bersikap hangat, memahami anak, mau mendengarkan pendapat dan cerita anak, memenuhi kebutuhan jasmani dan psikologis anak, dan sering memberikan anak pujian. 
Keluarga yang orangtuanya memiliki dimensi pola asuh parental responsiveness memilki hubungan yang baik dengan sang anak, dikarenakan kedua belah pihak sering melakukan diskusi terbuka dan terdapat proses memberi dan menerima. Orangtua dan anak saling mengekspresikan kasih sayang, empati dan simpati sebagai bukti penerimaan (Baumrind, dalam Papalia, et.al., 2012). Pada masa perkembangan anak, parental responsiveness menumbuhkan kehangatan, kepercayaan dalam hubungan, kepuasan pada diri sendiri dan merasa aman, ini semua dikarenakan adanya dukungan yang diberikan oleh orangtua kepada anak (Whipple, Bernier \& Megeau, dikutip dalam Ahmad, Vansteenkiste \& Soenens, 2012). Orangtua yang memiliki parental responsiveness tinggi akan menunjukkan sikap yang hangat dan memberikan afeksi dalam hubungan antara orangtua dengan anak. Sedangkan orangtua yang memiliki parental responsiveness rendah akan bersikap cuek dan cenderung terlihat kurang peduli. Orangtua juga cenderung mengkritik, membandingkan dan menghukum anaknya daripada memberikan pujian. Dari ketiga jenis pola asuh, pola asuh authoritative memiliki parental responsiveness yang tinggi, sedangkan pola asuh authoritarian dan pola asuh permissive memiliki parental responsiveness rendah (Levine \& Munsch, 2010).

Parental demandingness merupakan dimensi pola asuh di mana orangtua sangat menerapkan kontrol yang tinggi terhadap perilaku anak. Orangtua dengan dimensi ini memiliki standar yang tinggi dan menuntut anaknya untuk memenuhi standar tersebut. Jika sang anak tidak dapat memenuhi standar yang telah ditetapkan oleh orang tuanya, orangtua cenderung menghukum bahkan dapat berbuat kasar baik secara verbal maupun fisik (Baumrind, dalam Papalia et.al., 2012). Parental demandingness diekspresikan melalui pengendalian perilaku dan harapan orangtua adalah anak akan dianggap sebagai anggota keluarga jika sang anak mentaati semua peraturan orangtua dan anak harus bersikap disiplin senantiasa (Love $\&$ Thomas, 2014).
Orangtua dengan parental demandingness tinggi akan memaksakan banyak tuntutan dan membatasi perilaku anaknya. Orangtua memiliki banyak peraturan yang harus dipatuhi oleh anak. Sedangkan orangtua dengan parental demandingness rendah tidak terpaku pada kekuasaan dan kurang membatasi. Orangtua cenderung memberikan kebebasan pada anak dalam melakukan segala sesuatu. Dari ketiga jenis pola asuh, pola asuh authoritative dan pola asuh authoritarian memiliki dimensi parental demandingness yang tinggi, sedangkan pola asuh permissive memiliki dimensi parental demandingness yang rendah (Levine et al., 2010).

\section{METODE}

Karakteristik subyek pada penelitian ini adalah remaja dengan rentang usia 18 sampai 20 tahun, laki-laki maupun perempuan, serta memiliki Ayah dan Ibu yang masih hidup dan tinggal bersama dengan Ayah dan Ibu. Remaja yang menjadi subyek penelitian merupakan mahasiswa Universitas X di Jakarta. Menurut tabel Krejcie (dalam Nisfiannoor, 2013) dari yang disarankan untuk sebuah metodologi penelitian dengan jumlah populasi yang tidak diketahui, maka jumlah subyek yang diperlukan adalah sebanyak minimal 385 subyek. Oleh karena itu, jumlah subyek penelitian ini adalah sebanyak 386 subyek. Teknik pengambilan sampel yang digunakan adalah nonprobability sampling berupa accidental sampling. Accidental sampling adalah teknik penentuan sampel berdasarkan kebetulan, yaitu siapa saja yang secara kebetulan bertemu dengan peniliti dan dapat digunakan sebagai sampel, bila dilihat orang yang kebetulan ditemui itu cocok sebagai subyek penelitian..

Jenis penelitian ini merupakan penelitian kuantitatif non eksperimen untuk menguji peran sebuah variabel independen terhadap satu variabel dependen, yaitu menguji peran pola asuh terhadap prestasi belajar. Teknik pengumpulan data pada jenis 
penelitian ini dilakukan dengan cara menyebarkan instrumen penelitian.

Penelitian ini dilakukan di Universitas X yang berlokasi di Jakarta Barat. Peneliti menyebarkan 386 set kuesioner penelitian kepada mahasiswa Universitas $X$ yang berada di Jakarta Barat. Pada penelitian ini, penulis menggunakan alat ukur untuk pola asuh orangtua yang diisi oleh remaja. Alat ukur pola asuh terdiri dari dua bagian, yaitu hubungan dengan Ibu untuk mengukur pola asuh Ibu dan hubungan dengan Ayah untuk mengukur pola asuh Ayah. Alat ukur pola asuh ini terdiri dari beberapa pernyataan dengan lima alternatif jawaban, yaitu sangat tidak pernah (STP), tidak pernah (TP), kadang-kadang (KK), sering (SR) dan selalu (SLL).

Instrumen penelitian terdiri dari empat bagian, yaitu: (a) pengantar yang berisikan salam pembuka, perkenalan, informasi mengenai penelitian dan ucapan terimakasih; (b) informed consent yang terdiri dari pernyataan kesedian subyek dalam mengisi kuesioner serta tanda tangan subyek; (c) identitas diri yang berisikan data diri subyek yang harus dilengkapi, seperti nama, nomor induk mahasiswa (NIM), usia, tanggal lahir, jenis kelamin, suku bangsa, fakultas, semester, no telepon, alamat email, dan nilai IPK; dan (d) kuesioner untuk mengukur pola asuh.

\section{Pengukuran Variabel Pola Asuh Orangtua}

Alat ukur pola asuh orangtua menggunakan alat ukur yang dikembangkan oleh Bagian Riset dan Pengukuran Fakultas Psikologi, Universitas Tarumanagara. Alat ukur ini terdari dari dua jenis untuk mengukur pola asuh Ayah dan pola asuh Ibu. Alat ukur ini sesuai dengan teori pola asuh yang dikemukakan oleh Baumrind, Maccoby dan Martin.

\section{Pengukuran Variabel Prestasi Belajar}

Variabel prestasi belajar akan diukur melalui nilai Indeks Prestasi Kumulatif (IPK) terakhir subyek penelitian. Tinggi rendahnya prestasi belajar dapat diketahui melalui skor IPK. Semakin tinggi nilai IPK subyek penelitian, maka semakin tinggi pula prestasi belajar yang dicapai oleh subyek penelitian, dan sebaliknya.

HASIL

\section{Gambaran Umum Subjek Penelitian}

Penelitian ini melibatkan mahasiswa yang berada pada rentang usia 18 hingga 20 tahun, dengan frekuensi terbanyak adalah mahasiswa berusia 20 tahun sebanyak 166 orang atau $43 \%$, yang tersebar dari semester dua hingga delapan.

Tabel 1

Gambaran Umum Subjek Berdasarkan Usia

\begin{tabular}{lcc}
\hline Usia & Frekuensi & Persentase \\
\hline 18 tahun & 107 & 27.7 \\
19 tahun & 113 & 29.3 \\
20 tahun & 166 & 43 \\
\hline Jumlah & 386 & 100 \\
\hline
\end{tabular}

Tabel 2

Gambaran Umum Subjek Berdasarkan Semester

\begin{tabular}{ccc}
\hline Semester & Frekuensi & Persentase \\
\hline II & 165 & 42.7 \\
IV & 100 & 25.9 \\
VI & 117 & 30.3 \\
VIII & 4 & 1.0 \\
\hline Jumlah & 386 & 100 \\
\hline
\end{tabular}

Sebagian besar subjek merupakan perempuan, sebanyak 272 orang dengan persentase $70,5 \%$.

Tabel 3

Gambaran Umum Subjek Berdasarkan Jenis

Kelamin

\begin{tabular}{lcc}
\hline $\begin{array}{c}\text { Jenis } \\
\text { Kelamin }\end{array}$ & Frekuensi & Persentase \\
\hline Laki-Laki & 114 & 29.5 \\
Perempuan & 272 & 70.5 \\
\hline Jumlah & 386 & 100 \\
\hline
\end{tabular}


Tabel 4

Gambaran Umum Subyek Berdasarkan Fakultas

\begin{tabular}{lcc}
\hline Fakultas & Frekuensi & Persentase \\
\hline Ekonomi & 94 & 24.4 \\
Hukum & 20 & 5.2 \\
Psikologi & 118 & 30.6 \\
Ilmu & 42 & 10.6 \\
Komunikasi & & \\
Kedokteran & 33 & 8.5 \\
Seni Rupa & 19 & 4.9 \\
Desain & & \\
Teknik & 54 & 14 \\
Teknik & 7 & 1.8 \\
Informatika & & \\
\hline Jumlah & 386 & 100 \\
\hline
\end{tabular}

\section{Perbedaan Prestasi Belajar ditinjau dari} Pola Asuh Ayah

Pada penelitian ini terdapat empat jenis pola asuh yang ingin dilihat perbedaan nilai rata-ratanya. Berdasarkan hasil uji beda OneWay ANOVA, diketahui tidak terdapat perbedaan yang signifikan pada prestasi belajar ditinjau dari pola asuh Ayah. Hal ini ditunjukkan dengan nilai $\mathrm{F}=1.467$ dan nilai $\mathrm{p}=0.223>0.05$.

\section{Perbedaan Prestasi Belajar ditinjau dari Pola Asuh Ibu}

Pada bagian ini dilakukan uji beda menggunakan teknik analisis One-Way ANOVA untuk melihat perbedaan pada prestasi belajar ditinjau dari pola asuh Ibu. Hasil uji beda menunjukkan bahwa tidak terdapat perbedaan yang signifikan pada prestasi belajar ditinjau dari pola asuh Ibu. Hal ini ditunjukkan dengan nilai $\mathrm{F}=0.423$ dan nilai $\mathrm{p}=0.737>0.05$. Hasil analisis ini menunjukkan hasil yang sama dengan pola asuh Ayah.

\section{DISKUSI}

Penelitian ini menemukan bahwa tidak terdapat perbedaan prestasi belajar berdasarkan perbedaan pola asuh orangtua. Berdasarkan hasil temuan tersebut, nampaknya terdapat ketidaksesuaian dengan temuan sebelumnya yang mengatakan bahwa pola asuh orangtua memiliki hubungan dengan prestasi akademik anak (Baumrind, 1971; Maccoby \& Martin, 1983 dalam Papalia, Feldman, Martorell, 2012; Khayyer
\& Delacey dalam Nugrasanti, 2006; Steinberg dalam Banerjee \& Eccles, 2013; Santrock, 2016). Peneliti menduga bahwa ketidaksesuaian ini berasal dari tipe pola asuh yang diujikan, yakni hanya mencakup tiga tipe pola asuh dari Baumrind saja, sedangkan masih terdapat model-model atau tipe-tipe pola asuh yang lain yang dapat digunakan dalam penelitian ini. Selain itu, Tang dan Kean (2015) yang menemukan bahwa lingkungan rumah juga menentukan prestasi belajar remaja. Hal ini mengindikasikan bahwa masih terdapat variabel lain yang berasal dari keluarga dan orangtua yang berkontribusi terhadap prestasi belajar remaja yang masih belum terungkap dalam penelitian ini.

\section{SIMPULAN DAN SARAN}

Berdasarkan analisis data yang telah dilakukan oleh peneliti, hasil penelitian ini menunjukkan tidak ada perbedaan prestasi belajar pada remaja ditinjau dari pola asuh orangtua, baik pola asuh Ayah maupun pola asuh Ibu.

Peneliti menyarankan untuk penelitian selanjutnya agar semakin memperkaya disiplin ilmu yang berkaitan dengan topik penelitian ini. Pertama, penelitian selanjutnya dapat mengambil subyek penelitian dari seluruh universitas di wilayah Jakarta Barat secara proposional dengan menyetarakan standar pembelajaran yang ada di setiap fakultas pada masing-masing universitas. Peneliti mengambil subyek dari satu unversitas dikarenakan pengaruh faktor lain di luar variabel penelitian seperti perbedaan standar pembelajaran yang mungkin terdapat di univeristas yang berbeda. Selain itu juga dikarenakan peneliti membutuhkan bukti yang valid mengenai hasil prestasi belajar mahasiswa berupa nilai Indeks Prestasi Kumulatif (IPK) yang peneliti dapatkan dari biro kemahasiswaan.

Kedua, jika ingin melakukan penelitian yang berkaitan dengan prestasi belajar, disarankan untuk mencari variabel selain pola asuh, seperti self-efficacy, self-esteem, ataupun motivasi internal. Hal ini disebabkan karena terdapat kemungkinan bahwa pengaruh pola asuh orangtua telah berkurang 
pada diri mahasiswa yang berada pada tahapan remaja. Ketiga, penelitian selanjutnya juga dapat dilakukan dengan menggunakan subyek lain di luar mahasiswa, misalnya sperti siswa/i di jenjang Sekolah Menengah Atas atau Sekolah Menengah Pertama, karena tidak menutup kemungkinan pola asuh orangtua dan peran teman sebaya lebih terjadi pada populasi tersebut. Keempat, untuk penelitian selanjutnya adalah mengenai penggunaan alat ukur dalam mengumpulkan data. Peneliti menyarankan untuk menggunakan alat ukur yang lebih komprehensif sehingga dapat menggali jawaban subyek lebih mendalam.

\section{DAFTAR PUSTAKA}

Ahmad, I., Vansteenkiste, M., \& Soenens, B. (2012). The relations of Arab Jordanian adolescents' perceived maternal parenting to teacher-rated adjustment and problems: the intervening role of perceived need satisfaction. American Psychological Association. 1(49), 177183.

Altermatt, E. R. (2012). Friends' influence on school adjustment: Uncovering the processes of peer influence. In A. Ryan and G. Ladd (Eds.), Peer Relationships and Adjustment at School, 109-134. Charlotte, NC: Information Age Publishing.

Brooks, J. (2012). The process of parenting. (8th ed.). USA: McGrawHill.

Cobb, N.J. (2007). Adolescence: Continuity, change, and diversity. New York: McGraw Hill.

Conrad, C.S., \& Sarwono, S.W. (2010). Hubungan pola asuh orangtua dengan perilaku seksual remaja dalam berpacaran. Mindset, 1, 118-123.

Dehyadegary, E., Yaacob, S. N., Juhari, R. B., Talib, M. A. (2012). Relationship bertween parenting style and academic achievement among Iranian adolescents in Sirjan. Asian Social Science. 1(8), 156-160.
Kingsley, N. (2011). The influence of authoritative parenting style on adolescents' academic achievement. American Journal of Social and Management Sciences. DOI: 10.5251/ajsms.2011.2.3.278.282

Levine, L.E., \& Munsch, J. (2010). Child development. USA: SAGE.

Love, K. M., \& Thomas, D.M. (2014). Parenting styles and adjustment outcomes among college students. Journal of College Student Development, 2(55), 139-150.

Nisfiannoor, M. (2013). Pendekatan statistika modern. Jakarta: Universitas Trisakti.

Nugrasanti, R. (2006). Locus of control dan prokastinasi akademik mahasiswa. Jurnal Provitae, 1(2), 26-40.

Nurmah. (2011). Hubungan pola asuh orangtua dengan prestasi belajar anak usia sekolah kelas 2 dan 3 di SDN standar nasional Kayu Putih 09 Pagi Jakarta Timur tahun 2011. Jurnal STIKes MI,

Papalia, D., E., Feldman, R., D., \& Martorell, G. (2012). Experience human development. (12th ed.). NY: McGrawHill.

Pinquart, M. (2016). Association of parenting styles and dimensions with academic achievement in children and adolescent: A meta analysis. Educational Psychology Review, 28, 475-493.

Santrock, J., W. (2016). Adolescence (16th ed.). USA: McGraw Hill.

Sarwono, S., W. (2010). Akselerasi: A-Z Informasi program percepatan belajar dan anak berbakat intelektual. Jakarta: Grasindo.

Save The Children. (2016). Diunduh dari http://www.savethechildren.or.id/

Shaffer, D. R. (2010). Developmental psychology: Childhood \& adolescence. (15th ed.). USA: Brooks/Cole.

Shaffer, D. R \& Kipp, K. (2010). Developmental psychology: Childhood 
and adolescence. USA: Wadsworth Cangage Learning.

Suardi, M. (2012). Belajar dan pembelajaran. Yogyakarta: Deepublish.

Tang, S., \& Kean, P. E. D. (2015). The association of punitive parenting practices and adolescent achievement. Journal of Family Psychology, 29(6), 873-883

Turner, E. A, Chandler, M., \& Hefer, R. W. (2009). The influence of parenting styles, achievement motivation, and self-efficacy on academic performance in college students. Journal of college students development. 50(3), 337-346.

Yasmin, S \& Kiani, A. (2015). Role of parenting styles in academic performance of college students.

Weiten, W., Dumn, D.S., \& Hammer, E.Y. (2009). Pyschology applied to modern life. USA: Wadsworth Cangage Learning. 